\title{
Hubungan Stres dengan Kejadian Dismenore Primer pada Mahasiswi Pendidikan Dokter Fakultas Kedokteran Universitas Andalas
}

\author{
Diana Sari ${ }^{1}$, Adnil Edwin Nurdin ${ }^{2}$, Defrin $^{3}$
}

\begin{abstract}
Abstrak
Dismenore primer merupakan nyeri menstruasi yang dijumpai tanpa kelainan yang nyata pada alat-alat genital. Lebih dari $50 \%$ wanita mengalami dismenore primer dan $15 \%$ diantaranya mengalami nyeri yang hebat.Tujuan penelitian ini adalah untuk menentukan hubungan tingkat stres dengan derajat dismenore primer. Penelitian dilakukan pada mahasiswi pendidikan dokter Fakultas Kedokteran Universitas Andalas angkatan 2009 dan 2010. Desain penelitian ini menggunakan cross sectional study dengan jumlah subjek 165 orang. Pengumpulan data dari responden dilakukan dengan wawancara terpimpin (pengisian kuesioner). Analisa statistik yang digunakan adalah uji chi-square dan uji koefisien korelasi sederhana. Uji chi-square menunjukan ada hubungan yang bermakna antara stres dengan kejadian dismenore primer dan uji statistik koefisien korelasi sederhana menunjukkan ada hubungan yang bermakna dengan korelasi agak lemah antara tingkat stres dengan derajat dismenore primer.
\end{abstract}

Kata kunci: stres, dismenore primer, mahasiswi fakultas kedokteran

\begin{abstract}
Primary dysmenorrhoea is menstrual pain founded without real abnormalities in genital organs. More than 50\% woman experiance it and $15 \%$ had severe pain. The objective of this study was to determine relationship between stress and primary dysmenorrhoea. Research was executed to education medical female students medical faculty of Andalas University class of 2009 and 2010. This research use cross sectional study design with 165 subjects. Data was collected by guided interview. Statistic analysis use chi-square test and simple correlation test. Chi-square test show there is significant relationship between stress and primary dysmenorrhoea and simple coefficient test show there is weak correlation between stress levels and degree of primary dysmenorrhoea.
\end{abstract}

Keywords: stress, primary dysmenorrhoea, female student of medical faculty

\begin{abstract}
Affiliasi penulis: 1. Pendidikan Dokter FK UNAND (Fakultas Kedokteran Universitas Andalas Padang , 2. Bagian IImu Kesehatan Jiwa FK UNAND/RS Dr. M. Djamil Padang, 3. Bagian Kebidanan FK UNAND/RS Dr. M. Djamil Padang

Korespondensi: Diana Sari, E-mail: iidisa932@gmail.com, Telp: 085274629123
\end{abstract}

\section{PENDAHULUAN}

Setiap perempuan memiliki pengalaman menstruasi yang berbeda-beda, namun tidak sedikit yang mendapatkan menstruasi disertai keluhan sehingga menimbulkan rasa tidak nyaman berupa dismenore. ${ }^{1}$ Ada dua jenis dismenore yaitu: dismenore primer dan dismenore sekunder. ${ }^{2}$ Dismenore Primer biasanya terjadi pada umur kurang 20 tahun dan tidak ada hubungan dengan kelainan ginekologik, sedangkan dismenore sekunder terjadi setelah umur 20 tahun yang berhubungan dengan penyakit panggul yang nyata. $^{3}$

Dismenore primer sering terjadi pada lebih dari $50 \%$ wanita dan $15 \%$ diantaranya mengalami nyeri yang hebat. ${ }^{4}$ Dismenore primer dialami oleh $60-75 \%$ perempuan muda. Tiga perempat jumlah tersebut mengalami dismenore dengan intensitas ringan dan sedang, sedangkan seperempat lainnya mengalami dismenore dengan tingkat berat. $\mathrm{Di}$ Indonesia, kejadian dismenore primer mencapai $54,89 \% .^{5}$ 
Beberapa studi menyatakan bahwa dismenore dapat mengganggu aktivitas sehari-hari. ${ }^{6}$ Sekitar 10-15\% perempuan dapat absen dari sekolah dan kehilangan waktu bekerja karena dismenore. ${ }^{7}$

WHO memberi batasan remaja berdasarkan usia yaitu antara 12 sampai 24 tahun dan belum menikah. ${ }^{8}$ Masa remaja sebagai periode "badai dan tekanan" atau storm and stress", suatu masa dimana ketegangan emosi meningkat akibat perubahan fisik dan kelenjar yang menyebabkan remaja sangat sensitif dan rawan terhadap stress. ${ }^{8}$ Stress merupakan salah satu respon fisiologis, psikologis dan perilaku dalam beradaptasi terhadap tekanan internal dan eksternal. ${ }^{9}$

Penyebab stress pada mahasiswa kedokteran dapat bersumber dari dalam diri maupun dari luar, misalnya stress karena besarnya tuntutan orang tua akan prestasi akademik, maupun dari luar lingkungan sekitar, misalnya kelas kuliah yang tidak nyaman. Sumber stress pada mahasiswa kedokteran paling banyak berasal dari masalah kualitas makanan di asrama, tuntutan prestasi dari orang tua, kelas kuliah yang tidak nyaman, frekuensi ujian dan kurangnya waktu rekreasi. ${ }^{10}$

\section{METODE}

Penelitian ini merupakan jenis survey menggunakan studi analitik observasional dengan rancangan penelitian cross sectional. Penelitian dilakukan di Fakultas Kedokteran Universitas Andalas pada Juni 2012 - Februari 2013. Subjek penelitian adalah semua populasi yang hadir saat penelitian. Data dikumpulkan dari data primer yang diperoleh dari pengisian kuesioner oleh responden dan dikembalikan langsung pada hari penelitian. Langkah-langkah pengolahan data adalah pemeriksaan kelengkapan dan kejelasan data, pemberian kode pada setiap data variabel, memasukkan data dalam program aplikasi komputer, serta pemeriksaan kembali untuk memastikan bahwa data tersebut telah bersih dari kesalahan. Analisis data terdiri dari analisis univariat dan bivariat. Pada analisis bivariat dicari hubungan antara dua variabel dengan menggunakan uji chisquare.
HASIL

Tabel 1. Frekuensi stres

\begin{tabular}{ccc}
\hline Stres & $\mathbf{F}$ & $\%$ \\
\hline Tidak & 59 & 35,8 \\
Ya & 106 & 64,2 \\
\hline Total & 165 & 100,0 \\
\hline
\end{tabular}

Tabel 1 menunjukkan bahwa 64,2\% mahasiswi pendidikan dokter Fakultas Kedokteran Universitas Andalas mengalami stres, sedangkan $35,8 \%$ tidak mengalami stres.

Tabel 2. Frekuensi dismenore primer

\begin{tabular}{ccc}
\hline Dismenore & $\mathbf{F}$ & $\%$ \\
\hline Tidak & 33 & 20,0 \\
Ya & 132 & 80,0 \\
\hline Total & 165 & 100,0 \\
\hline
\end{tabular}

Tabel 2 diatas menunjukkan bahwa 80,0\% mahasiswi pendidikan dokter Fakultas Kedokteran Universitas Andalas mengalami dismenore primer, sedangkan $20,0 \%$ tidak mengalami dismenore primer.

Tabel 3. Distribusi tingkat stres

\begin{tabular}{ccc}
\hline Stres & $\mathbf{f}$ & $\%$ \\
\hline Ringan & 74 & 44,8 \\
Sedang & 21 & 12,7 \\
Berat & 11 & 6,7 \\
\hline Total & 106 & 100,0 \\
\hline
\end{tabular}

Berdasarkan Tabel 3 didapatkan mahasiswi pendidikan dokter paling banyak mengalami stress ringan (44,8\%), kemudian $12,7 \%$ mengalami stress sedang dan $6,7 \%$ mengalami stress berat.

Tabel 4. Distribusi derajat dismenore primer

\begin{tabular}{ccc}
\hline Stres & $\mathbf{F}$ & $\%$ \\
\hline Ringan & 53 & 32,1 \\
Sedang & 40 & 24,1 \\
Berat & 39 & 23,6 \\
\hline Total & 132 & 100,0 \\
\hline
\end{tabular}

Tabel 4 menunjukkan bahwa 32,1\% mahasiswi 
pendidikan dokter mengalami dismenore primer ringan, 24,2\% mengalami dismenore sedang dan $23,6 \%$ mengalami dismneore berat.

Tabel 5. Hubungan stress dengan kejadian dismenore primer

\begin{tabular}{lcccccc}
\hline \multirow{2}{*}{ Stress } & \multicolumn{3}{c}{ Dismenore } & \multicolumn{2}{c}{ Total } \\
\cline { 2 - 6 } & \multicolumn{2}{c}{ Ya } & \multicolumn{2}{c}{ Tidak } & \multicolumn{1}{c}{} \\
\cline { 2 - 6 } & $\mathbf{f}$ & $\%$ & $\mathbf{F}$ & $\%$ & $\mathbf{F}$ & $\%$ \\
\hline Ya & 100 & 94 & 6 & 5 & 106 & 100 \\
Tidak & 32 & 54 & 27 & 46 & 59 & 100 \\
\hline Total & 132 & 80 & 33 & 20 & 165 & 100 \\
\hline
\end{tabular}

Berdasarkan Tabel 5 terlihat bahwa kejadian dismenore primer lebih banyak terjadi pada responden yang mengalami stress (94\%).

Tabel 6. Hubungan tingkat stress dengan derajat dismenore primer

\begin{tabular}{lcccccccccc}
\hline \multirow{2}{*}{$\begin{array}{l}\text { Tingkat } \\
\text { Stres }\end{array}$} & \multicolumn{9}{c}{ Tingkat Dismenore } & \multirow{2}{*}{ Total } \\
\cline { 2 - 9 } & \multicolumn{1}{c}{ Tidak } & \multicolumn{1}{c}{ Ringan Sedang } & \multicolumn{3}{c}{ Berat } & & \\
\cline { 2 - 9 } & $\mathbf{F}$ & $\%$ & $\mathbf{f}$ & $\%$ & $\mathbf{F}$ & $\%$ & $\mathbf{f}$ & $\%$ & $\mathbf{f}$ & $\%$ \\
\hline Tidak & 28 & 47 & 13 & 22 & 8 & 13 & 11 & 18 & 60 & 100 \\
Ringan & 3 & 4 & 40 & 54 & 18 & 24 & 13 & 18 & 74 & 100 \\
Sedang & 3 & 15 & 0 & 0 & 11 & 55 & 6 & 30 & 20 & 100 \\
Berat & 0 & 0 & 0 & 0 & 2 & 18 & 9 & 82 & 11 & 100 \\
\hline Total & 34 & 21 & 53 & 32 & 39 & 24 & 39 & 24 & 165 & 100 \\
\hline
\end{tabular}

Tabel 6 diatas menunjukkan bahwa responden yang mengalami dismenore primer ringan paling banyak dialami oleh responden yang mengalami stress ringan (54\%). Responden yang mengalami dismenore sedang sebanyak $55 \%$ dan responden yang mengalami dismenore berat paling banyak dialami oleh responden yang mengalami stress berat (82\%). Berdasarkan uji statistik yang diperoleh nilai $p=0,6$. Dapat disimpulkan bahwa terdapat hubungan yang bermakna dengan korelasi sedang antara tingkat stress dengan derajar dismenore primer pada mahasiswi pendidikan dokter Fakultas Kedokteran Universitas Andalas.

\section{PEMBAHASAN}

a. Hubungan stress dengan kejadian dismenore primer

Berdasarkan hasil penelitian didapatkan kejadian dismenore primer lebih tinggi pada responden yang mengalami stress dibandingkan dengan responden yang tidak mengalami stress. Faktor stress ini dapat menurunkan ketahanan terhadap rasa nyeri. Pada saat stress, tubuh akan memproduksi hormon estrogen dan prostaglandin yang berlebihan. Estrogen dan prostaglandin ini dapat menyebabkan peningkatan kontraksi uterus secara berlebihan sehingga mengakibatkan rasa nyeri saat menstruasi. Hormon adrenalin juga meningkat dan menyebabkan otot tubuh tegang termasuk otot rahim dan menjadikan nyeri saat menstruasi.

b. Hubungan tingkat stress dengan derajat dismenore primer

Peningkatan tingkat stress dapat menyebabkan nyeri haid. Peningkatan aktivitas saraf simpatis yang menyebabkan peningkatan nyeri menstruasi dengan peningkatan kontraksi uterus.

\section{KESIMPULAN}

Terdapat hubungan antara stress dengan kejadian dismenore primer dan terdapat hubungan yang bermakna dengan korelasi sedang antara tingkat stress dengan derajat dismenore primer.

\section{DAFTAR PUSTAKA}

1. Paramita DP. Hubungan tingkat pengetahuan tentang dismenora dengan perilaku penanganan dismenora pada siswa SMK YPKK 1 Sleman Yogyakarta (skripsi). Surakarta: Jurusan Kebidanan Fakultas Kedokteran Universitas Sebelas Maret; 2010.

2. Hacker, Nevilla F. Essentials of obstetrics and gynecology. Philadelphia: Elsevier's Health Sciences Rights Department; 2004.

3. Morgan G, Hamilton C. Obstetri dan ginekologi panduan praktis. Jakarta: EGC; 2003.

4. Novia D. Hubungan dismenora dengan olahraga pada remaja usia 16-18 tahun di SMA ST. Thomas 1 Medan (skripsi). Medan: Fakultas Kedokteran Universitas Sumatera Utara; 2009.

5. Fitriyah $\mathrm{Y}$. Hubungan antara stres dengan kejadian dismenora primer (skripsi). Semarang: Fakultas Psikologi Universitas Diponogoro; 2009.

6. Lu,I-Chen. Dymenorrha and related factors in Taiwanesa Adolescent Girls (disertation). Austin: Universitas of Texas; 2010. 
7. Wang L. Stres and dysmenorrheal: a population based propective study. Occup Environ Med. 2004;61:1021-6.

8. Isnaeni DN. Hubungan antara stress dengan pola menstruasi D IV Kebidanan jalur reguler Universitas Sebelas Maret Surakarta (skripsi). Surakarta: Jurusan Kebidanan Fakultas Kedokteran Universitas Sebelas Maret. 2010.
9. Sukhraini I. Hubungan stres dengan siklus menstruasi yang tidak teratur pada mahasiswa kedokteran USU angkatan 2007 (skripsi). Medan: Fakultas Kedokteran Universitas Sumatera Utara; 2007.

10. Carolin. Gambaran tingkat stres pada manusia (skripsi). Medan: Fakultas Kedokteran Universitas Sumatera Utara; 2010. 